\title{
A Positive Conversion in HER2 Status Might Affect Survival after Liver Resection for Breast Cancer Metastases
}

\author{
Kadri Altundag \\ MKA Breast Cancer Clinic, Tepe Prime, Ankara, Turkey
}

To the Editor,

I wish to congratulate Ercolani et al. [1] for their article in which they reviewed their experience with liver resection for metastases from breast cancer in $51 \mathrm{pa}-$ tients. They concluded that liver resection is a safe and effective treatment for metastases from breast cancer, and encouraging long-term survival can be obtained with acceptable risk in selected patients. However, the authors did not provide detailed infor- mation about the relation of immunohistochemical receptor status between primary and metastatic tumors (only seven patients' data were available). A change of estrogen receptor, progesterone receptor, and HER2 status in distant metastases has frequently been reported. The actual incidence of this phenomenon has been debated. Recent meta-analysis including 39 studies assessing receptor conversion from primary breast tumors to paired distant breast cancer metastases showed that negative to positive conversion percentages were 21.5, 15.9 , and $9.5 \%$ for estrogen receptor, progesterone receptor, and HER2 [2]. The positive conversion in HER2 status literally changes the treatment challenges in these patients favoring the use of adjuvant antiHER2 targeted armamentarium, which in turn might affect the survival.
References
Ercolani G, Zanello M, Serenari M, et al: Tenyear survival after liver resection for breast metastases: a single-center experience. Dig Surg 2018, DOI: 10.1159/000486523.
Schrijver WAME, Suijkerbuijk KPM, van Gils $\mathrm{CH}$, et al: Receptor conversion in distant breast cancer metastases: a systematic review and meta-analysis. J Natl Cancer Inst 2018, Epub ahead of print.
Kadri Altundag MD

MKA Breast Cancer Clinic Tepe Prime, Cankaya TR-06800 Ankara (Turkey) E-Mail altundag66@yahoo.com 